\title{
Video Media to Improve the Learning Outcomes of Class II Students of SD Negeri 1 Candiwulan
}

\section{Dwi Jayanti Ispiandari}

SD Negeri 1 Candiwulan

dwijayantiispiandari@gmail.com

\section{Article History}

accepted 01/11/2020

approved 08/11/2020

published $15 / 11 / 2020$

\begin{abstract}
The purpose of this research is to improve the learning outcomes of students on Theme 4 Clean and Healthy Living. The method for this research is classroom action research with the research subjects of class II students totaling 19 children at SD Negeri 1 Candiwulan. The instruments used are assessment of learning plans, assessment of the learning process, assessment of social attitudes, assessment of learners' skills, and assessment of knowledge. Achievement of percentage results obtained from cycles I, II, and III has increased. In the first cycle the percentage attainment was $73 \%$ with sufficient criteria, in the second cycle the percentage achievement was $80 \%$ with good criteria, and in the third cycle the percentage achievement was $88.4 \%$ with good criteria. So, it can be said that the use of video media can improve student learning outcomes in theme 4 of clean and healthy living.
\end{abstract}

Keywords: Video media, learning outcomes

\begin{abstract}
Abstrak
Tujuan penelitian ini adalah untuk meningkatkan hasil belajar siswa pada Tema 4 Hidup Bersih dan Sehat. Metode penelitian ini adalah penelitian tindakan kelas dengan subjek penelitian siswa kelas II yang berjumlah 19 anak di SD Negeri 1 Candiwulan. Instrumen yang digunakan adalah penilaian rencana pembelajaran, penilaian proses pembelajaran, penilaian sikap sosial, penilaian keterampilan peserta didik, dan penilaian pengetahuan. Persentase pencapaian hasil yang diperoleh dari siklus I, II, dan III mengalami peningkatan. Siklus I persentase pencapaiannya $73 \%$ dengan kriteria cukup, siklus II persentase pencapaian $80 \%$ dengan kriteria baik, dan siklus III persentase pencapaian $88,4 \%$ dengan kriteria baik. Jadi, dapat dikatakan bahwa penggunaan media video dapat meningkatkan hasil belajar siswa pada tema 4 hidup bersih dan sehat.

Kata kunci: Media video, hasil belajar
\end{abstract}

Social, Humanities, and Education Studies (SHEs): Conference Series https://jurnal.uns.ac.id/shes 


\section{PENDAHULUAN}

Pembelajaran tematik terpadu merupakan pendekatan Kurikulum 2013 pada jenjang SD/MI. Pembelajaran tematik terpadu merupakan pendekatan pembelajaran yang mengintegrasikan berbagai kompetensi dari berbagai mata pelajaran kedalam berbagai tema. Dalam pembelajaran tematik terpadu, tema yang dipilih berkenaan dengan alam dan kehidupan manusia. Untuk kelas I, II, dan III, keduanya merupakan pemberi makna yang substansial terhadap mata pelajaran PPKn, Bahasa Indonesia, Matematika, Seni-Budaya dan Prakarya, serta Pendidikan Jasmani, Olahraga dan Kesehatan. Di sinilah Kompetensi Dasar dari IPA dan IPS yang diorganisasikan ke mata pelajaran lain memiliki peran penting sebagai pengikat dan pengembang Kompetensi Dasar mata pelajaran lainnya. Dari sudut pandang psikologis, peserta didik belum mampu berpikir abstrak untuk memahami konten mata pelajaran yang terpisah kecuali kelas IV, V, dan VI sudah mulai mampu berpikir abstrak. Penggunaan media pembelajaran sangat berperan dalam proses pembelajaran tematik terpadu, karena peserta didik pada jenjang SD kelas II masih dalam tahapan berpikir konkret.

Secara umum di kelas II SD Negeri 1 Candiwulan, dalam mengajar guru hanya mengunakan media gambar yang ada di buku siswa. Bagi peserta didik media gambar kurang menarik perhatian mereka, karena peserta didik sudah terbiasa disajikan gambar-gambar dalam buku tema. Penggunaan media gambar yang terus menerus juga menyebabkan rendahnya motivasi dan keaktifan peserta didik dalam mengikuti pembelajaran. Hal ini berdampak pada rendahnya hasil belajar peserta didik kelas II di SD Negeri 1 Candiwulan.

Menurut Aqib (2011), penelitian tindakan kelas adalah penelitian yang dilakukan oleh guru di kelasnya sendiri melalui refleksi diri dengan tujuan untuk memperbaiki kinerjanya sehingga hasil belajar siswa meningkat. Menurut O'Brien (Mulyatiningsih, 2011), penelitian tindakan kelas adalah penelitian yang dilakukan ketika sekelompok orang (siswa) diidentifikasi permasalahannya, kemudian peneliti (guru) menetapkan suatu tindakan untuk mengatasinya. Menurut Kemmis dan Taggart (Padmono, 2010), penelitian tindakan kelas adalah suatu penelitian refleksif diri kolektif yang dilakukan oleh peserta-pesertanya dalam situasi sosial untuk meningkatkan penalaran dan keadilan praktik pendidikan dan praktik sosial mereka, serta pemahaman mereka terhadap praktik-praktek itu dan terhadap situasi tempat dilakukan praktik-praktek tersebut.

Hasil belajar merupakan kemampuan-kemampuan dimiliki siswa setelah menerima pengalaman belajarnya. Kemampuan-kemampuan tersebut mencakup aspek kognitif, afektif dan psikomotorik. Hasil belajar dapat dilihat melalui kegiatan evaluasi yang bertujuan untuk mendapatkan data pembuktian yang akan menunjukkan tingkat kemampuan siswa dalam mencapai tujuan pembelajaran. Hasil belajar yang diteliti dalam penelitian ini ialah hasil belajar peserta didik pada tema 4 hidup bersih dan sehat yang mencakup muatan pelajaran Bahasa Indonesia, Matematika, dan SBdP. Instrumen yang digunakan untuk mengukur hasil belajar siswa pada aspek kognitif ialah tes.

Menurut Mulyasa "2008", hasil belajar ialah prestasi belajar siswa secara keseluruhan yang menjadi indikator kompetensi dan derajat perubahan prilaku yang bersangkutan. Kompetensi yang harus dikuasai siswa perlu dinyatakan sedemikian rupa agar dapat dinilai sebagai wujud hasil belajar siswa yang mengacu pada pengalaman langsung. Menurut Winkel "Dikuti Oleh Purwanto, 2010", hasil belajar ialah perubahan yang mengakibatkan manusia berubah dalam sikap dan tingkah lakunya. Menurut Sudjana "2010", hasil belajar ialah kemampuan-kemampuan yang dimiliki siswa setelah ia menerima pengalaman belajar.

Video adalah gambar-gambar dalam frame di mana frame demi frame diproyeksikan melalui lensa proyektor secara mekanis sehingga pada layar terlihat gambar itu hidup. Media ini pada umumnya digunakan untuk tujuan-tujuan hiburan, 
dokumentasi, dan pendidikan. Video dapat menyajikan informasi, memaparkan proses, menjelaskan konsep-konsep yang rumit, mengajarkan keterampilan, menyingkat atau memperpanjang waktu, dan mempengaruhi sikap.

Menurut Dwyer, video mampu merebut 94\% saluran masuknya pesan atau informasi kedalam jiwa manusia melalui mata dan telinga serta mampu untuk membuat orang pada umumnya mengingat $50 \%$ dari apa yang mereka lihat dan dengar dari tayangan program. Pesan yang disampaikan melalui media video dapat mempengaruhi emosi yang kuat dan juga dapat mencapai hasil cepat yang tidak dimiliki oleh media lain.

Menurut Cheppy Riyana (2007) media video pembelajaran adalah media yang menyajikan audio dan visual yang berisi pesan-pesan pembelajaran baik yang berisi konsep, prinsip, prosedur, teori aplikasi pengetahuan untuk membantu pemahaman terhadap suatu materi pembelajaran. Video merupakan bahan pembelajaran tampak dengar (audio visual) yang dapat digunakan untuk menyampaikan pesan-pesan/materi pelajaran. Dikatakan tampak dengar kerena unsur dengar (audio) dan unsur visual/video (tampak) dapat disajikan serentak.

Berdasarkan latar belakang masalah di atas, maka dirumuskan masalah sebagai penelitian perbaikan pembelajaran yaitu" Apakah penggunaan media video dapat meningkatkan hasil belajar Tema 4 Hidup Bersih dan Sehat pada peserta didik kelas II di SD Negeri 1 Candiwulan?" dan "Bagaimana penggunaan media video dapat meningkatkan hasil belajar Tema 4 Hidup Bersih dan Sehat pada peserta didik kelas II di SD Negeri 1 Candiwulan?". Tujuan yang ingin dicapai dari penelitian ini yaitu untuk mengetahui apakah penggunaan media video dapat meningkatkan hasil belajar Tema 4 Hidup Bersih dan Sehat pada peserta didik kelas II di SD Negeri 1 Candiwulan dan untuk mengetahui bagaimana penggunaan media video dapat meningkatkan hasil belajar Tema 4 Hidup Bersih dan Sehat pada peserta didik kelas II di SD Negeri 1 Candiwulan. Untuk itu penulis melakukan penelitian yang lebih mendalam tentang "Penggunaan Media Video Dalam Upaya Meningkatkan Hasil Belajar Tema 4 Hidup Bersih dan Sehat Pada Peserta Didik Kelas II di SD Negeri 1 Candiwulan”.

\section{METODE}

Penelitian ini merupakan penelitian tindakan kelas (PTK) yang dilaksanakan dalam 3 siklus. Setiap siklus terdiri 3 tahap yaitu perencanaan, pelaksanaan, observasi, dan refleksi. Subjek penelitian yaitu peserta didik kelas II SD Negeri 1 Candiwulan yang berjumlah 19 peserta didik yang terdiri dari 5 peserta didik laki-laki dan 14 peserta didik perempuan. Sumber data dalam penelitian ini adalah peserta didik kelas II SD Negeri 1 Candiwulan dan teman sejawat sebagai observer selama pelaksanaan proses perbaikan pembelajaran. Data yang dikumpulkan dalam penelitian ini adalah data kualitatit dan data kuantitatif. Data kualitatif berupa data penyususnan rencana pembelajaran, data proses pembelajaran, dan data perubahan sikap sosial pada peserta didik. Sedangkan data kuantitatif berupa data hasil pembelajaran pada aspek keterampilan dan aspek pengetahuan dalam bentuk tes formatif. Teknik pengumpulan data dalam penelitian tindakan kelas ini adalah berupa observasi, tes, dan dokumentasi. Lembar observasi digunakan untuk menilai kinerja guru dan aktifitas peserta didik dalam proses pembelajaran. Tes hasil belajar digunakan untuk mengukur keberhasilan proses belajar yang telah dilakukan dengan menerapkan penggunaan media video yang berdampak pada hasil belajar. Analisis data hasil penelitian tindakan kelas dengan analisis data sederhana. Untuk menganalisis dan menginterpretasi data dapat menggunakan tabel konversi yaitu data kualitatif dapat dikonversi menjadi kuantitatif atau sebaliknya. 
SHEs: Conference Series 3 (3) (2020) 470- 478

HASIL DAN PEMBAHASAN

Berdasarkan analisis hasil penelitian yang telah diuraikan, maka pembahasan pada penelitian ini sebagai berikut:

Tabel 1

Rekapitulasi Hasil Penelitian Siklus I, II, dan III

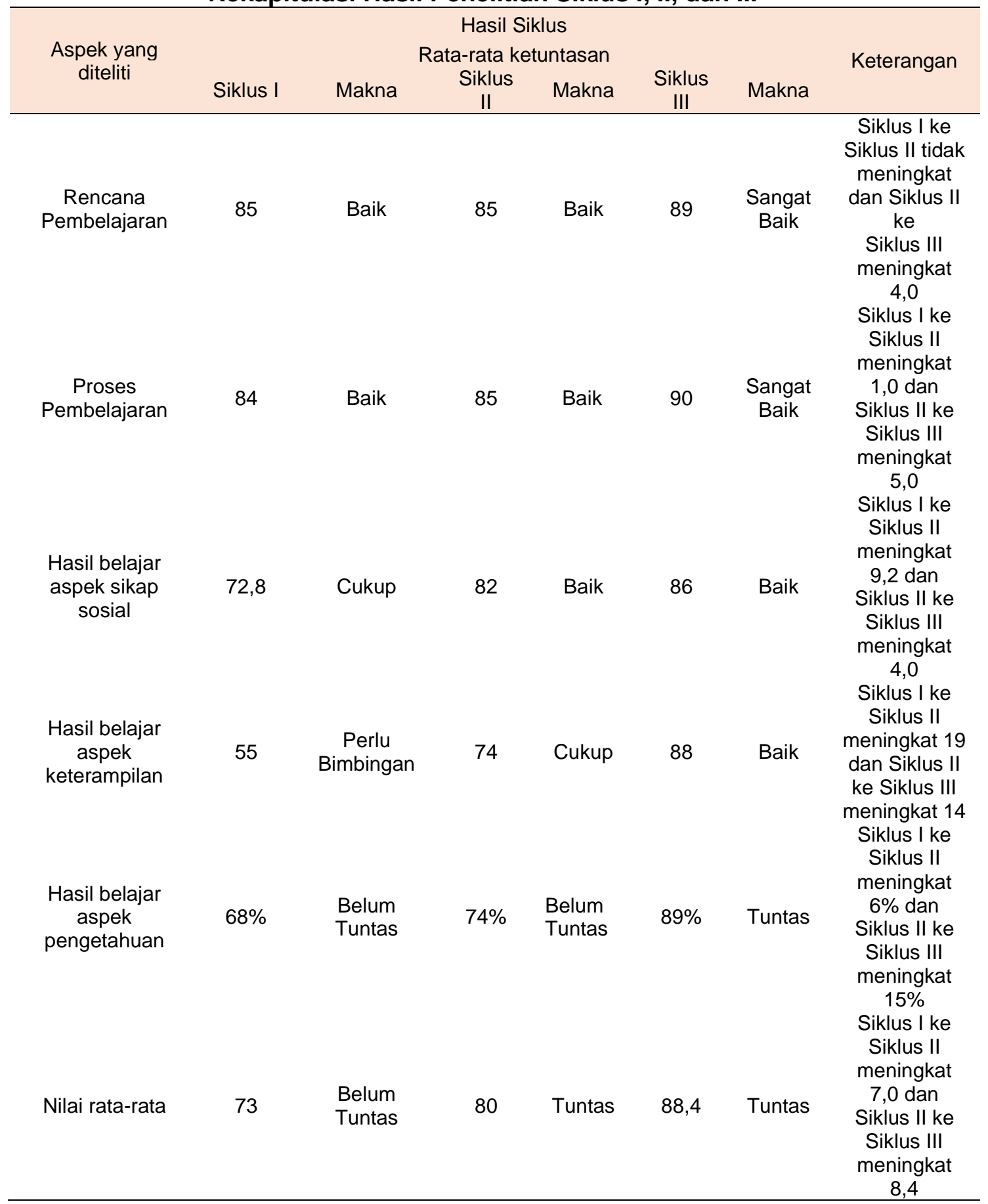

a. Rekapitulasi Rencana Pelaksanaan Pembelajaran

Untuk menjelaskan data hasil penilaian rencana pelakanaan pembelajaran pada siklus I, II dan III dapat dilihat pada diagram di bawah ini. 


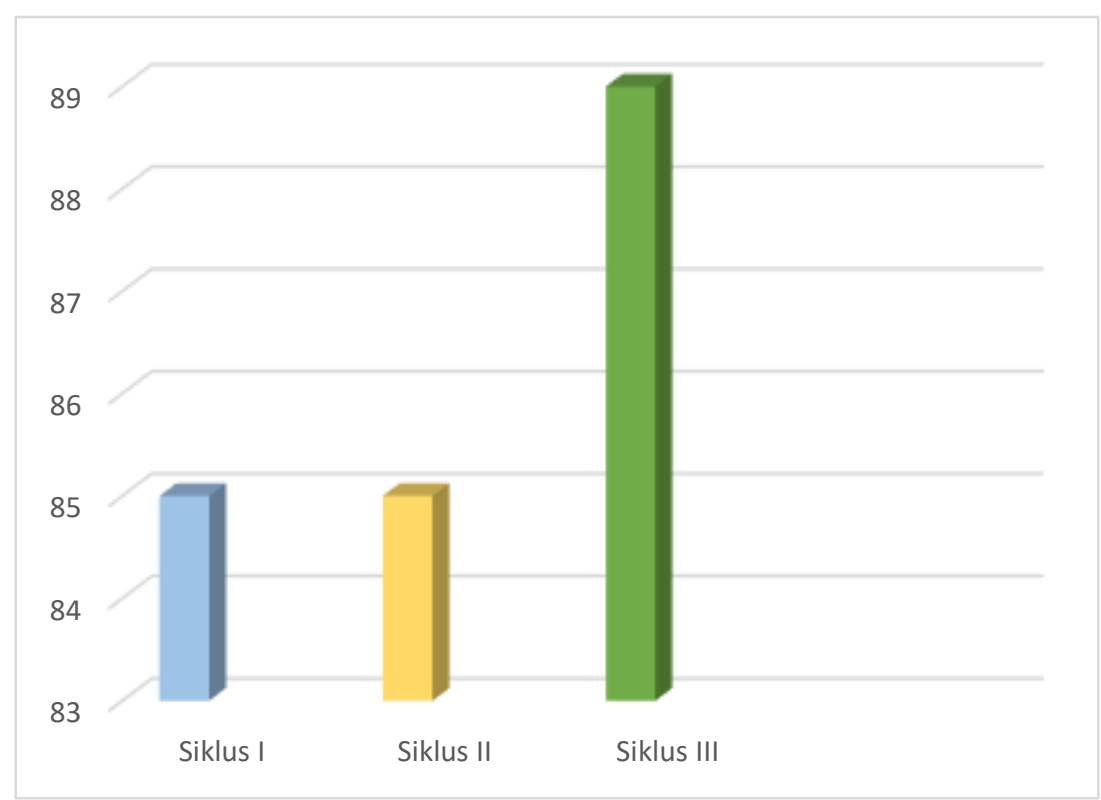

\section{Gambar 1. Diagram Batang Rekapitulasi Rencana Pelaksanaan Pembelajaran Siklus I, II, dan III}

Berdasarkan diagram di atas keberhasilan terjadi pada rencana pelaksanaan pembelajaran di kelas secara daring terlihat dari nilai setiap siklus. Pada siklus I sebesar 85 dengan interpretasi baik. Pada siklus II sebesar 85 interpretasi baik. Pada siklus III meningkat menjadi 89 dengan interpretasi sangat baik.

\section{b. Rekapitulasi Proses Pelaksanaan Pembelajaran}

Untuk menjelaskan data hasil penilaian proses pelakanaan pembelajaran pada siklus I, II, dan III dapat dilihat pada diagram di bawah ini.

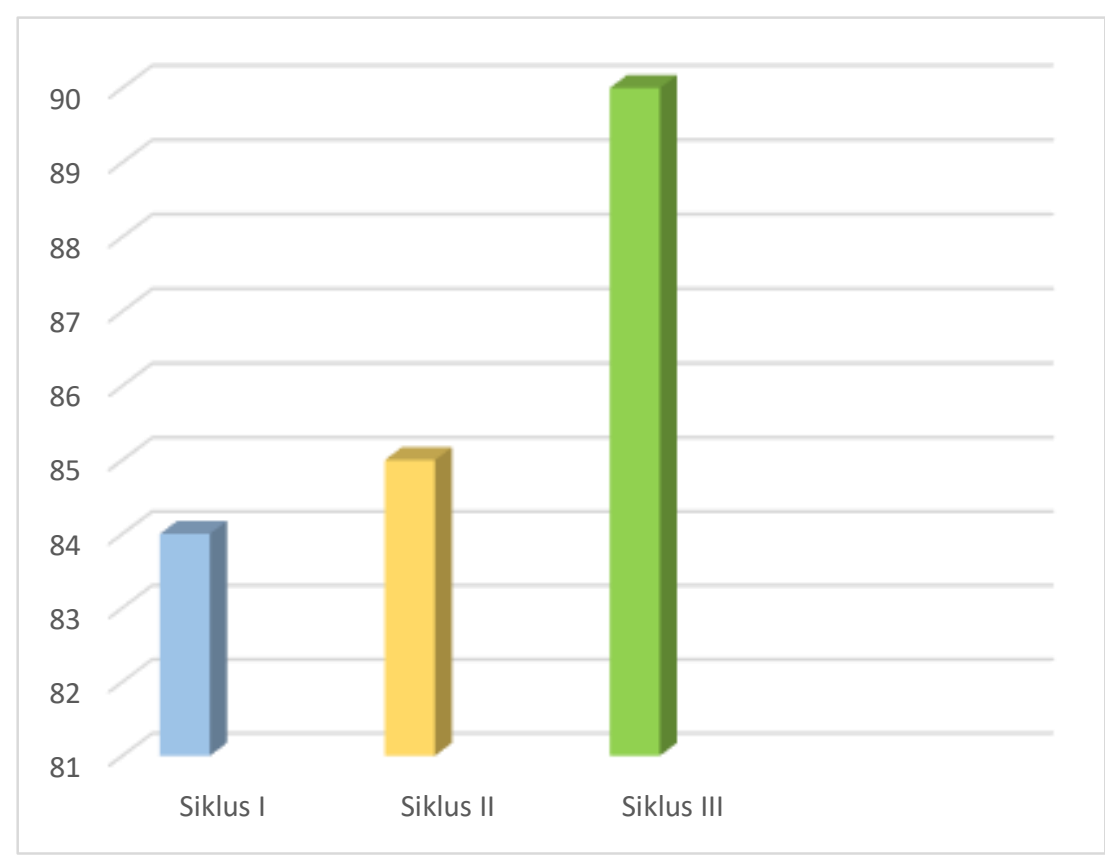

Gambar 2. Diagram Batang Rekapitulasi Proses Pembelajaran Siklus I, II, dan III 
Berdasarkan diagram di atas keberhasilan terjadi pada proses pembelajaran di kelas secara daring terlihat dari nilai setiap siklus. Pada siklus I sebesar 84 dengan interpretasi baik. Pada siklus II sebesar 85 dengan interpretasi baik. Kemudian pada siklus III sebesar 90 dengan interpretasi amat baik.

\section{c Rekapitulasi Hasil Belajar Aspek Sikap}

Untuk menjelaskan data hasil penilaian proses pelaksanaan pembelajaran pada siklus I, II, dan III dapat dilihat pada diagram di bawah ini.

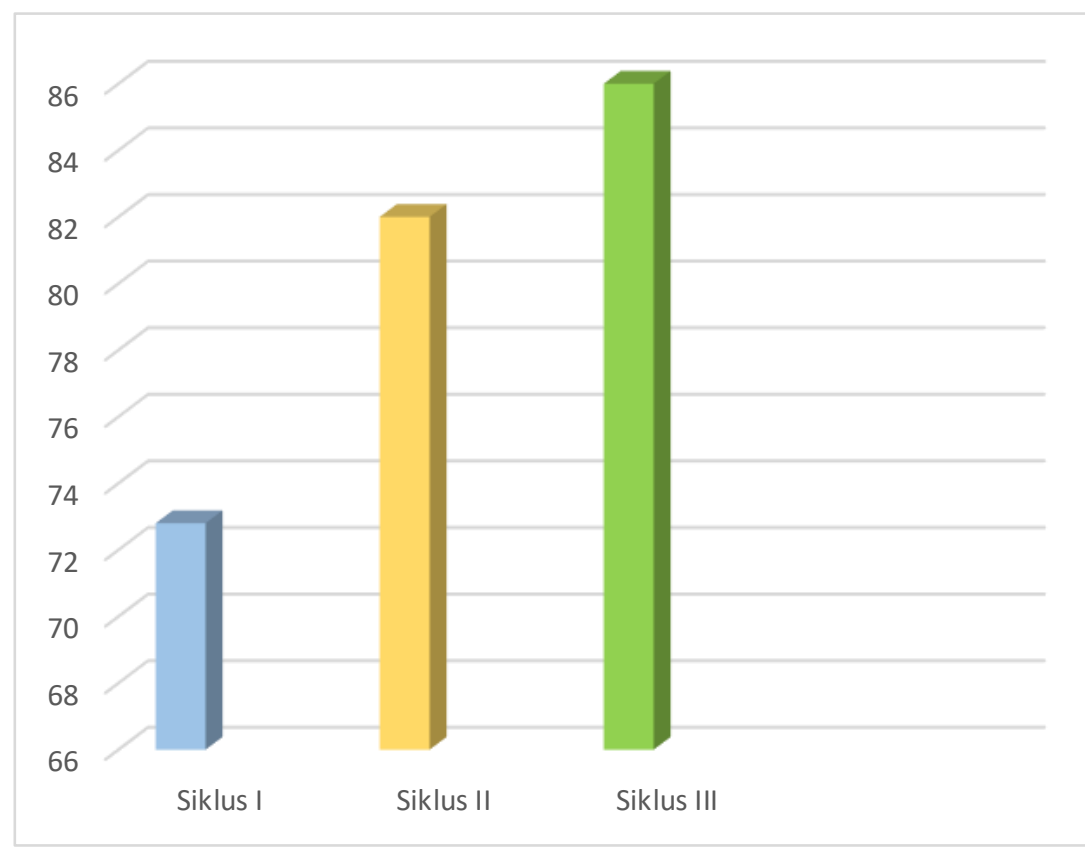

\section{Gambar 3}

Diagram Batang Rekapitulasi Hasil Belajar

Aspek Sikap Sosial Siklus I, II, dan III

Berdasarkan diagram di atas keberhasilan terjadi pada proses pembelajaran di kelas secara daring terlihat dari nilai setiap siklus. Pada siklus I sebesar 72,8 dengan interpretasi cukup. Pada siklus II sebesar 82 dengan interpretasi baik. Kemudian pada siklus III sebesar 86 dengan interpretasi sangat baik.

\section{d Rekapitulasi Hasil Belajar Aspek Keterampilan}

Untuk menjelaskan data hasil penilaian proses pelakanaan pembelajaran pada siklus I, II, dan III dapat dilihat pada diagram di bawah ini. 


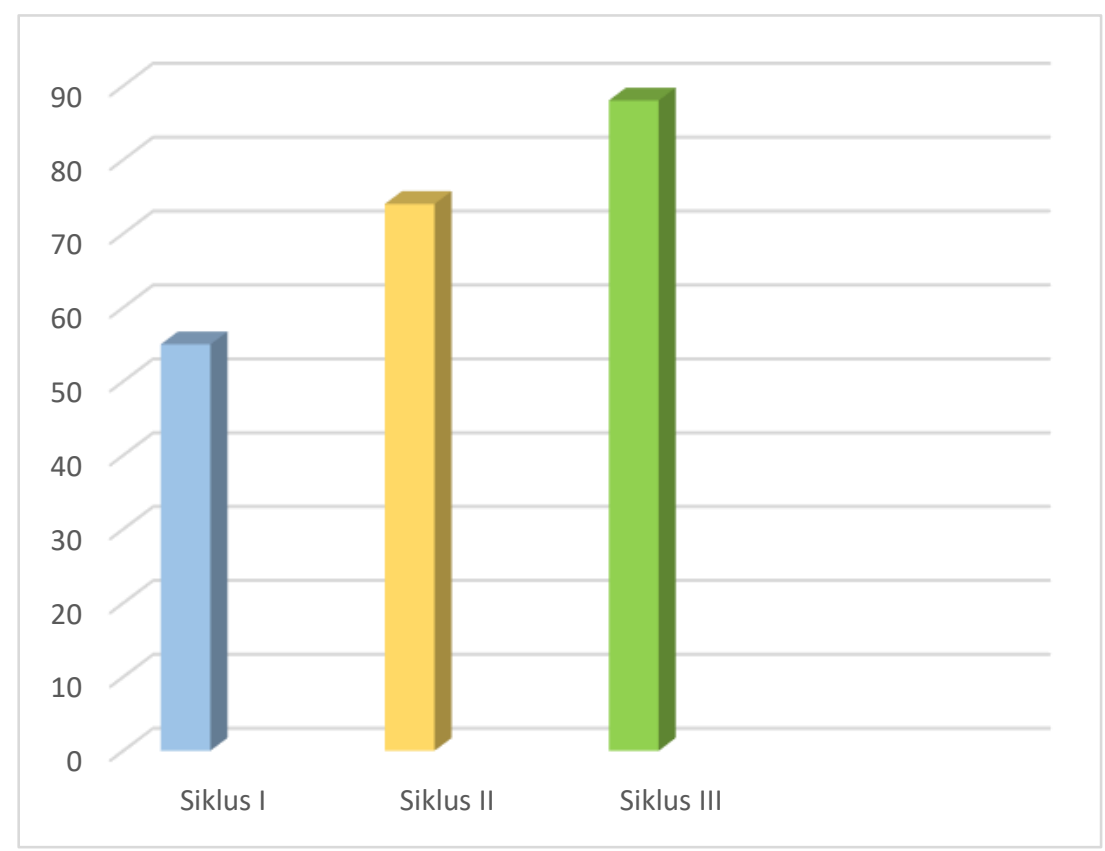

\section{Gambar 4 \\ Diagram Batang Rekapitulasi Hasil Belajar Aspek Ketrampilan Siklus I, II, dan III}

Berdasarkan diagram di atas keberhasilan terjadi pada proses pembelajaran di kelas secara daring terlihat dari nilai setiap siklus. Pada siklus I sebesar 55 dengan interpretasi perlu bimbingan. Pada siklus II sebesar 74 dengan interpretasi cukup. Kemudian pada siklus III sebesar 88 dengan interpretasi sangat baik.

\section{e Rekapitulasi Hasil Belajar Aspek Pengetahuan}

Untuk menjelaskan data hasil penilaian proses pelakanaan pembelajaran pada siklus I, II, dan III dapat dilihat pada diagram di bawah ini.

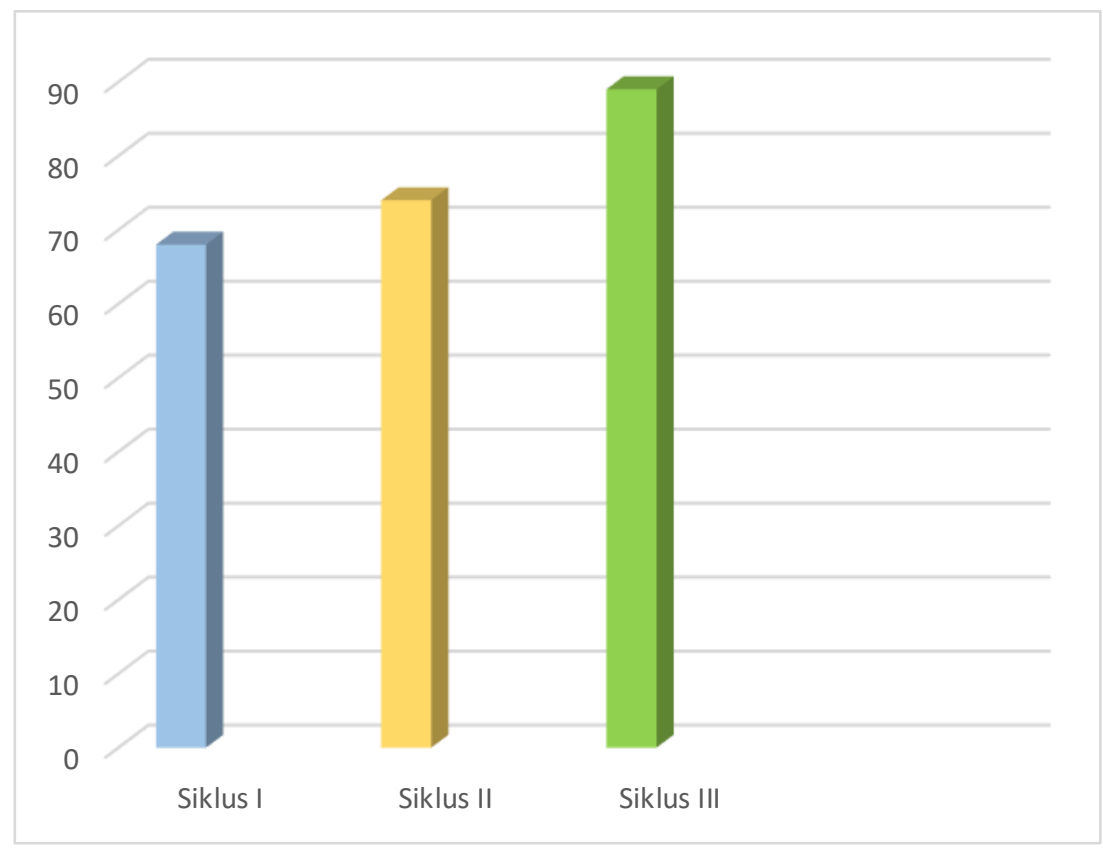




\section{Gambar 5. Diagram Batang Rekapitulasi Hasil Belajar Aspek Pengetahuan Siklus I, II, dan III}

Hasil belajar aspek pengetahuan peserta didik menunjukkan pada siklus I 13 peserta didik mencapai ketuntasan atau $68 \%$. Kemudian pada Siklus ke II meningkat menjadi 14 peserta didik mencapai ketuntasan atau 74\%. Dan pada Siklus III meningkat kembali menjadi 17 peserta didik mencapai ketuntasan atau 89 $\%$.

\section{SIMPULAN}

Berdasarkan hasil penelitian pada pembelajaran tema 4 hidup bersih dan sehat dengan menggunakan media video untuk meningkatkan hasil belajar peserta didik kelas II SD Negeri 1 Candiwulan, maka dapat diperoleh simpulan yaitu proses pelaksanaan pembelajaran dengan menggunakan media video dapat meningkatkan hasil belajar peserta didik pada tema 4 hidup bersih dan sehat di SD Negeri 1 Candiwulan yang dilaksanakan sesuai dengan rencana pembelajaran yang telah dibuat. Pencapaian hasil prosentase yang diperoleh dari siklus I, II, dan III mengalami peningkatan. Pada siklus I pencapaian prosentase yang diperoleh sebesar $73 \%$ dengan kriteria cukup, pada siklus II pencapaian hasil prosentase yaitu $80 \%$ dengan kriteria baik, dan pada siklus III pencapaian hasil prosentase yaitu $88,4 \%$ dengan kriteria baik. Dilihat dari prosentase akhir kinerja guru, maka proses pembelajaran dengan menggunakan media video sudah memenuhi standar yang ditetapkan dan hasil belajar peserta didik meningkat sehingga dapat dikatakan penelitian ini berhasil. Peneliti hendaknya menggunakan pendektan dan metode yang sama untuk mengatasi permasalahan pembelajaran yang sama. Peneliti juga harus selalu menggunakan media pembelajaran yang menarik sehingga dapat meningkatkan motivasi dan keaktifan peserta didik yang berdampak pada peningkatan hasil belajar peserta didik.

\section{DAFTAR PUSTAKA}

Majid, Abdul. 2014. Pembelajaran Tematik Terpadu. Bandung: PT. Remaja Rosdakarya

Arikunto, Suhardjono dan Supardi. 2006. Penelitian Tindakan Kelas. Jakarta: Bumi Aksara.

Aqib, Zainal, dkk. 2011. Penelitian Tindakan Kelas untuk Guru SD, SLB, dan TK. Bandung: Yrama Widya.

Mulyatiningsih, Endang. 2011. Metode Penelitian Terapan Bidang Pendidikan. Bandung: Alfabeta.

Hopkins, David. 1993. A Teacher's Guide to Classroom Research. Philadelphia: Open University Press.

Mufarokah, Anissatul. 2009. Strategi Belajar Mengajar. Yogyakarta: TERAS

Sanjaya, Wina. 2008. Perencanaan dan Desain Sistem Pembelajaran. Jakarta: Kencana

Sanjaya, Wina. 2006. Strategi Pembelajaran. Jakarta: Prenada Media 